\title{
OBITUARIES
}

\section{Dr. R. A. Frazer, F.R.S.}

THe news of the death of Dr. R. A. Frazer at his home in Ockham on December 10 was received with much sadness by his former colleagues at the National Physical Laboratory, and particularly by those who had had the privilege of working with him or under his leadership. His unselfishness, charm, modesty and humour made him a most likeable person and he will be sadly missed by many friends. His scientific ability and distinguished bearing inspired respect in all who met him, and his kindliness won the affection of all those who had the good fortune to know him well.

Dr. Frazer had a brilliant career as a mathematician at Cambridge and was a Rayleigh Prizeman. $\mathrm{He}$ joined the staff of the National Physical Laboratory in 1914, his first post being that of assistant secretary in administration. After about a year he was transferred to a group engaged in aerodynamic research in the Engineering Division. This group of pioneers in aeronautics became the nucleus around which the Aerodynamics Division was formed a few years later.

During the first ten years or so of Frazer's career as a research worker, his mathematical talent was put to good use in the study of problems of viscous flow, but from time to time he took part in other investigations. Some of the work he did in connexion with full-scale tests on the airship $R .38$ resulted in his winning the $R .38$ Memorial Prize awarded by the Royal Aeronautical Society.

It was characteristic of him to do everything he attempted with great thoroughness, and he was never satisfied until he had unravelled all aspects of any problem, however complicated, on which he happened to be engaged. He had remarkable power for concentration and when deeply immersed in a problem would lose all sense of time.

It was not surprising that, when aireraft flutter became a serious problem around about 1924, Frazer was asked to investigate what was then a mysterious phenomenon. By wind tunnel tests on simple aircraft models of reduced elasticity, and by analysis, he and his co-workers were soon able to obtain a physical understanding of flutter and to discover methods for its prevention. With W. J. Duncan as co-author he published in 1928 the first flutter monograph, and this is now often referred to as the 'flutter bible'. In this book the phenomenon is clearly explained by reference to simple systems, and the basic theory for the prediction of critical speeds for flutter is fully developed. His study of flutter theory led him to take an interest in matrix algebra for the purpose of analysing complicated systems involving many degrees of freedom. The outcome of this work was a book on "Elementary Matrices", written with Duncan and Collar as co-authors. This is now regarded as a classic on the subject, and it has had a profound world-wide influence on the development of methods of flutter and vibration analysis and on the general theory of aero-elasticity.

In recognition of his outstanding work he was elected a Fellow of the Royal Society in 1946. $\mathrm{He}_{\mathrm{e}}$ was also a Fellow of the Royal Aeronautical Society and of the Institute of the Aeronautical Sciences, and was a member of the Oscillation Sub-Committee of the Aeronautical Research Council. Formerly he was also a member of the Mechanics Committee.

Immediately after the Second World War, the National Physical Laboratory was asked to investigate the possibility of wind-excited oscillations of suspension bridges, in connexion with the proposal to erect suspension bridges across the Severn and the Forth. It was feared that, like the Tacoma bridge, these bridges would fail unless they were properly designed to avoid such instability. Again it was Dr. Frazer who took responsibility for the investigation. With the assistance of C. Scruton and other members of the Division, he designed and made a 50-ft. long reduced elasticity model for testing in a specially crected wind tunnel at Thurleigh. In due course they were able to reproduce on the model the kind of oscillation that destroyed the Tacoma bridge and show how it could be avoided by suitable design. As a result of their investigations they were able to propose a design for the Severn and Forth Suspension Bridges which was not prone to instability in the strongest winds. A bridge to this design is now being built ovor the Firth of Forth.

Outside his work, Dr. Frizer had many interests. In his younger days he was a keen mountaineer and enjoyed nothing better than climbing in the Alps, the Lake District and North Wales. He was also a member of Oxford Univorsity Expeditions to Spitsbergen in 1921, 1923 and 1924. In later years his main interest was gardening. When he retired in 1954 after forty years service, everyone hoped that he would have good health to enjoy a long and happy retirement with his family, but this was not to be.

Dr. Frazer's name will live long in aeronautical history, and he will always be remembered with esteem and affection by many friends who feel the deepest sympathy with his wife and family in their bereavoment.

W. P. JONES

\section{Prof. Anrezej Soltan}

THE death has been announced of Dr. Anrezej Soltan, director of the Polish Institute of Nuclear Research since 1955. Born in 1897, Dr. Soltan was a member of the Scientific Council, Joint Institute for Nuclear Research, Dubna, U.S.S.R., a member of the Polish Academy of Sciences, and he hold the position of chairman of the Central Administration of the Polish Physical Society during 1952-54.

Soltan was educated at the University of Warsaw and carried out scientific work in France during 1927-28 and in the United States during 1932-33. His publications cover the fields of spectroscopy, physical chemistry of hydrogen and mercury vapour, the interaction of fast neutrons with atomic nuclei and the isomeric radioisotope of bromine.

After the War he became professor at Lodz Polytechnic (1945-47), returning to the University of Warsaw as professor of experimental physics (194748 ) and then as professor of atomic physics.

Dr. Soltan was a delegate at the Second International Conference on the Peaceful Uses of Atomic Energy at Geneva in 1958 and was a member of the State Council for the Peaceful Uses of Nuclear Energy. 